\title{
Interaction between Participatory Non-formal Environmental Education Programme and Education Level of Adult Learners on Their Environmental Knowledge and Attitude in Oyo State, Nigeria
}

\author{
Flora O. Nkire \\ Department of Educational Foundations \\ Faculty of Education \\ Abia State University, Uturu, Nigeria
}

\begin{abstract}
Unfriendly environmental behaviours resulting from people's poor environmental knowledge and attitude (KA) have placed Oyo state at the risk of incessant environmental disasters in recent time. In Nigeria generally Education Level has not proven to be a strong determinant of people's Environmental $(K A)$. Moreover previous efforts at Environmental Education (EE) in Nigeria have been majorly centred on children in schools while the peripheral attempt at the non-formal sector has been nonparticipatory in nature. This study examined the extent of the interaction effect of participatory nonformal EE programme and education level of the adult learners on their environmental (KA). 154 nonformal adult learners from 2 adult literacy centres in Oyo State were purposively selected for the study. 5 instruments were used and 2 null hypotheses were tested There was significant interaction effect of participatory EE programme and education level on adult learners' environmental knowledge and attitude. Participatory Non-formal EE Programme was recommended for the adult learners as it has the capacity of reaches out to people of varying education levels
\end{abstract}

\section{Introduction}

Oyo State is strategically located in the South Western geopolitical zone of Nigeria. It is one of the six states carved out of the old Western region of the country. The state has an estimated population of $6,617,720$ and occupies an area of $28,454 \mathrm{~km}^{2}$. It is bounded by the states of Kwara on the north, Osun on the east, and Ogun on the south and by the Republic of Benin on the west Oyo state is reputed as one of the with highest number of urban centres in the country. These include Ibadan (capital city), Eruwa, Igbo-Ora, Igboho, Ilora, Isoyin, Keshi, Ogbomoso, Okeho, Oyo and Saki. Most of its area particularly in the south is covered by the rain forest while the north is largely by the 'derived' savannah resulting from clearing and burning of the former forest cover to provide land for cultivation. The mean temperatures of the state are usually high even during the rainy season and ranges between $24^{\circ} \mathrm{C}$ and $35^{\circ} \mathrm{C}$ [1]. The main economic activities of the people include agriculture, timber lumbering, and crafts.

Ibadan the Oyo state capital city was founded in the 1800s. It was said to have been settled as a war camp in 1829 by groups of victorious soldiers from the other parts of the region namely Ife, Ijebu and Oyo who defeated the Owu kingdom [2]. This heterogeneous nature of the founders of Ibadan in the first instance and followed by the landmark events of naming the city at different periods of its existence as the regional, provincial, divisional and district headquarters in the old Western region culminated in its rapid growth to the point of once being regarded as the largest indigenous city in the tropical Africa.

Oyo state occupies a strategic position in the history of Nigeria and Africa generally as it is reputed for hosting the first University in Nigeria, first Teaching hospital in Nigeria, first Television station in Africa and the internationally acclaimed International Institute of Tropical Agriculture (IITA), first stadium in Nigeria and first skyscraper (popular Coca House) built in Africa. However the state is currently beset with the menace of environmental disasters resulting from uncontrollable urbanization, poor urban plan, poor disposal and management of solid and liquid wastes, poor drainage systems and deforestation. Its state capital territory which spans twelve out of the thirty three local government areas of the state has been noted for incessant flood disasters almost on an annual bases causing loss of thousands of lives and properties worth billions of Naira

According to [3] flood disasters are associated with the unnecessary risks people take when they encroach on the flood plains and that there will be no flood disasters if human beings stay away from the flood plan. They however lamented that due to rapid urbanization the city of Ibadan has spread beyond the drainage basins of Ogunpa and Kudeti andto the catchment area of Ogbere stream. Its spread has extended to Odo-Ona and these are the major rivers that drain the metropolis. Consequently these rivers have constantly overflown their banks resulting in the disastrous flooding the area has suffered in recent times [4]. These have been attributed to poor 
environmental knowledge and attitude of its citizenry [5], [6].

With the high level of illiteracy in Nigeria, the tendency has been to blame the problems of environmental degradation on the poor environmental knowledge and attitude of the illiterate masses [7]. However [8] observes that Nigerians of high education levels are major contributors to the nation's environmental degradation problems. He argues that the highly educated in the country play key roles in causing problems of gully erosion threatening the highways and requiring huge sums of money to control, poor drainage system resulting in flood, deforestation, hazardous pollutants, oil spillage as well as damming of the rivers without proper watershed management. He further noted that some of these professionals, in their various fields as contractors, bid to win contracts, to construct roads, bridges, build industries, office and business complexes, estates, and quarters without adequate Environmental Impact Assessment (EIA). Some still indulge in importing harmful chemicals into the country. There is also the "War on Nigeria's Wetland" story as told by [9]] which has to do with the craze among the very rich and educated Nigerians to live at the waterfronts in Lagos which provoked an unprecedented land reclamation project along the coastal areas. This is therefore a strong indication that in Nigeria one's level of education may not be judged a determining factor for his environmental knowledge and attitude.

Most of the previous attempts at modifying people's environmental knowledge and attitude were however directed at students in the formal education sector while those who are outside the formal school system and who incidentally form the larger percentage of the people who degrade the environment most are not adequately targeted to enable them to be at the fore-front in turning around the environment for the better [10]. This may not be unconnected to the widely held view that parents learn about it from their children who learn about it in school [11]. . In a related study carried out by [12] it was reported that there was a dearth of literature specifically on the sector of non-formal EE. They therefore affirmed that this is due to the misleading idea held by some people that "adults are set in their ways, as such, there is no point trying to change their behaviours", thus, justifying the decision to concentrate on educating children in schools. In a counter argument [13] had earlier asserted that adults as a matter of fact are more likely than children to be significant players in communities, groups and locality. He further noted that the adults are able to "enthuse and organize" and possess the necessary awareness upon which to base political action and to influence and educate others. Hence, there is the need for environmental educators to support the adults to active, critical and creative EE engagements [14]. The [15] report presented at the World Summit on Sustainable Development in Johannesburg noted that the major reason for focusing on adult education for sustainable development is that it would be unwise to wait for the present generation of school and college students to grow up and begin applying what they are learning.

Part of the premise on which the Adult Nonformal $\mathrm{EE}$ is established emphasizes that majority of the world's population who in their quest for survival engage in all manner of environmental unfriendly activities still outside the formal school system.

This study therefore examined the extent of the interaction effect of participatory non-formal Environmental Education (EE) programme and education level of the adult learners on their environmental knowledge and attitude. One hundred and fifty-four non-formal adult learners in intact classes from two adult literacy centres in Oyo State were purposively selected for the study. The two adult literacy centres were randomly assigned to experimental and control groups and the study lasted twelve weeks. Five instruments were used for data collection. Data collected were analyzed using Analysis of Covariance.

\section{Hypotheses}

Two hypotheses were tested at 0.05 level of significance.

1. There is no significant interaction effect of Participatory Non-formal EE Programme and education level on the adult learners' environmental Knowledge.

2. There is no significant interaction effect of the Participatory Non-formal EE Programme and education level on the adult learners' environmental attitude

\section{Results}

\subsection{Hypothesis 1}

There is no significant interaction effect of the Participatory Non-formal EE Programme and education level on the adult learners' Environmental knowledge.

Summary of ANCOVA of Posttest Knowledge Score by Treatment and Education level reveals that there is a significant interaction effect of treatment and education level on adult learners' environmental knowledge $\left(\mathrm{F}_{(1,153)}=6.385 . \mathrm{p}<.05\right)$. Hypothesis 1 is hereby rejected.

In order to explain the nature of this interaction, interaction Effect of Treatment and Education level on Environmental Knowledge shows that among the participants in the low education level, the participatory instruction was more effective than the conventional instruction. In the same vein, the participatory EE programme was also more effective 
than the conventional instruction for the learners in high education level.

\subsection{Hypothesis 2}

There is no significant interaction effect of the Participatory Non-formal EE Programme and education level on the adult learners' Environmental Attitude.

Summary of ANCOVA of Posttest Attitude by Treatment and Education Level shows that the interaction effect of treatment and education level is significant on participants environmental attitude $\left(F_{(1,153)}=13.629 ; p<0.05\right)$. On this basis, hypothesis 2 is rejected. To explains this interaction, Interaction Effect of Treatment and Education Level on Environmental Attitude shows that the participatory EE programme was more effective for the adult learners in both the low and the high education levels than the conventional instructional method.

\section{Discussion}

\subsection{Education Level and Adult Learners' Environmental Knowledge and Attitude}

The findings of this study reveals that the environmental knowledge and attitude of the adult learners in both high and low education levels who were exposed to the participatory EE programme were significantly higher than those in the conventional instruction group This implies that that the Participatory EE Programme significantly influenced the participants' environmental knowledge and attitude.

This is an indication that the Participatory EE programme developed and implemented in the course of this study was not education level biased particularly at the level of the adult learners' environmental knowledge and attitude. It positively influenced the adult learners' environmental knowledge and attitude irrespective of their education levels. This may be attributed to the active-learner participatory nature of the Participatory EE programme in which the adult learners were exposed to a democratized learning setting. This therefore confirms the efficacy of EE programmes that emphasize teaching/learning approaches that goes beyond theory but incorporates practical activities as [16] reiterated. This by its nature, according to [17] reaches out and involves different classes of people in activities which encourage community participation as the role of the teacher is not that of a purveyor of knowledge for rote learning and subsequent regurgitation [18] but that of a learner as well as a facilitator as he shares from the learning opportunities and then implement collective actions and decision-making [19].

\section{Conclusion}

This study which was motivated by the concern for the terrific level of deterioration on Nigerian environment and Oyo state in particular, will serve as an attempt to adequately target the adults who constitute the larger percentage of Nigerian population that degrade the environment most with EE progammes that involve them actively in finding solutions to the problems they play major roles in generating.

It is therefore recommended that adult learners should be exposed to Participatory Non-formal EE Programmes during which they would be given the opportunity to actively participate in developing their skills, create sense of commitment and stimulate individual and collective actions towards the environment. Adult Educators should be trained in the development and use of Participatory EE Programmes through capacity building workshop series. Curriculum experts in EE and Adult Education should work together to ensure adequate utilization of Participatory EE Programmes for the adults both in the Literacy Centres and other settings such as the workplace, religious organizations, vocational centres, trade unions,

\section{References}

[1] O. Odesina, Oyo State, Wikipedia, the free Encyclopedia, 2012, 1-5.

[2] L. Fourchard, The Case of Ibadan, Nigeria, Institut Francais de Rocherche en Afrique, University of Ibadan, 2002, 1-27.

[3] O. Ajayi et al, Flood Management in an Urban Setting: A case Study of Ibadan Metropolis, Hydrology for Disaster Management, Publication of Nigeria Association of Hydrological Science, 2012, 65-81.

[4] O. Tomori, Flood Disaster in Nigeria : Historical Origin. 2010.

[5] World Wide Funds for Nature (WWF), Climate News, 2008.

[6] J. O. Ajiboye and S.O. Ajiton, Effects of full and quasiparticipatory learning strategies on Nigerian senior secondary students' environmental knowledge: Implications for classroom practice, International journal of environment and science education 2008, 3(2), 58-66.

[7] J. O. Ajiboye and S.O. Ajiton, Effects of full and quasiparticipatory learning strategies on Nigerian senior secondary students' environmental knowledge: Implications for classroom practice, International journal of environment and science education 2008, 3(2), 58-66.

[8] S.W. Petters, Rationale, Nature and Scope of Environmental Education, Nigeria Conservation Foundation Module 1. Nigeria: Macmillan Publishers Ltd, 1995. 
[9] WWF.War on Nigerian Wetlands. Connet, 1999.

[10] Okeke, Environment and Development in Coastal Regions and in Small Islands: Education and Sustainable c Coastal Development, University of Nigeria, Nsukka, 2004.

[11] National Environmental Education and Training Foundation (NEETF), The National Report Card on Environmental Knowledge, Attitudes and Behaviours, Washington DC, 1997, 1-36.

[12] Guevara, Flowers \& Griffits, Popular and Informal Environmental Education: The need for more research in an emerging field of practice. Australian Journal of Environmental Education. 2006.

[13] D. Slattery, Adult Education and Ecology, Australian Journal of Environmental Education. Vol. 15-16. 85-93, 2000.

[14] D. Clover, Environmental Adult Education in Canada: Growing Jobs for Living. Australian Journal of Environmental Evaluation. Vol. 114-116, 1998.

[15] UNESCO, A Report Presented at the World Summit on Sustainable Development. Johannesburg, 2002.

[16] U.M. Nzewi, Review Strategies for Teaching Water Pollution, Environmental Education Series, No. 1, 30-39, 1998.

[17] A. I. Madumere Environmental Programmes as Indispensable tool for Enriching Public Environmental Education in Nigeria. Proceedings of the $1^{\text {st }}$ Annual Conference of Science Teachers Association of Nigeria. Nigeria: HEBN Publishers Plc, 2000.

[18] S.P.T. Gbamaja, Keynote address on STAN Environmental Education ConferencE, 1998.

[19] M. Sato, Evolving Environmental Education and its relation to Education and Population and Information for Human Environment (EPD) and Education for Sustainable Development (ESD), 2006. 